\title{
Large-scale pseudotachylytes and fluidized cataclasites from an ancient subduction thrust fault
}

Christen D. Rowe ${ }^{1}$, J. Casey Moore ${ }^{1}$, Francesca Meneghini ${ }^{2}$, Alexander W. McKeirnan ${ }^{3}$

${ }^{1}$ University of California Santa Cruz, Earth Science Department, 1156 High St., Santa Cruz, California 95064

${ }^{2}$ Université di Pisa, Dipartimento di Scienze della Terra, via S. Maria, 53, 56126-Pisa, Italia

${ }^{3}$ The Pennsylvania State University, Department of Geosciences, 320 Deike Building, University Park, Pennsylvania 16802

\begin{abstract}
In the Kodiak accretionary complex, Kodiak Island, Alaska, pseudotachylyte occurs in black, locally vitreous ultrafine-grained fault rock. Microscopic observations show that the pseudotachylytes are composed of glass, with vesicles, amygdules, microlites, and flow structures, indicating a frictional melt. The pseudotachylyte is gradational to cataclasite and shows outcrop-scale injection and ductile deformation structures. The cataclasite was ductily mobile (i.e., fluidized) simultaneous with the formation and emplacement of pseudotachylyte melt. The pseudotachylytic rocks postdate the stratal disruption fabric of associated shear-zone me'langes and show similar direction of thrust transport, and have undergone limited subsequent deformation. We interpret the stratal disruption as resulting from underthrusting of the subducting plate and pseudotachylyte development as the final activity of this thrust surface. The gradational contacts between pseudotachylyte and cataclasite demonstrate that the cataclasite also formed as a seismic product and may represent paleoseismic rupture zones, possibly of very great earthquakes, with or without accompanying pseudotachylytes. The pseudotachylytes are voluminous, and many are spatially disconnected from generation surfaces. This style is distinct from pseudotachylytes described in other environments, and this may explain the rarity of documented examples of subduction-thrust pseudotachylyte.
\end{abstract}

\section{INTRODUCTION}

Subduction thrust faults generate the world's largest earthquakes and are the site of $90 \%$ of global moment release (Pacheco et al., 1993). Studies of exhumed subduction complexes provide the only means of geologically observing the seismogenic zone. However, explicit geological evidence of paleoseismicity in subduction-zone rocks exhumed from seismogenic depths has been elusive. Fisher and Byrne (1987) recognized that mélange zones preserved in accretionary prisms represent ancient subduction thrust faults. However, deformation in these systems is broadly distributed. Ikesawa et al. 
(2003), Austrheim and Andersen (2004), and Kitamura et al. (2005) discovered direct evidence of paleoseismicity as frictional melts or pseudotachylytes in ancient subduction thrust faults. These pseudotachylytes satisfy the strictest criteria for identifying paleoseismicity (Cowan, 1999). Pseudotachylyte-bearing faults are uniquely able to record dynamic rupture processes during earthquakes (Bjørnerud and Magloughlin, 2004; Lan-Bin et al., 1997) . Given that the majority of modern subduction zones are seismogenic, direct evidence of paleoseismicity seems strangely absent in the rock record.

\section{Pseudotachylytes}

Many pseudotachylytes are associated with cataclasites, suggesting that ultracomminution is a stage in the development of pseudotachylyte, and possibly a necessary precursor (Bjørnerud and Magloughlin, 2004; Magloughlin, 1992; Spray, 1995). It is the general consensus that both ultracataclasis and frictional melting play a role in pseudotachylyte formation (Magloughlin, 1992), and that pseudotachylytes are formed exclusively during seismic slip (Sibson, 1975). Otsuki et al. (2003) documented association of cataclasite and pseudotachylyte horizons in the Nojima fault zone over millimeter scales, reinforcing the genetic relationship between cataclasis and melting.

\section{GEOLOGIC SETTING}

The Kodiak accretionary complex (Fig. 1) comprises a mid-Mesozoic to early Tertiary accretionary prism constructed of accreted, NW-dipping, thrust-bounded units. These rock units are progressively younger toward the southeast, with modern equivalents forming in the Aleutian Trench (Plafker et al., 1994). Décollement-system thrust faults are preserved in several accreted units, recording the history of the de'collement during its activity at some discrete depth (Fisher and Byrne, 1987).

The structurally lowest part of the Paleocene Ghost Rocks Formation of the accretionary complex is an argillaceous mélange and Fisher and Byrne's (1987) prime example of a décollement zone. We have studied this mélange at Pasagshak Point, where it primarily consists of variably disrupted turbiditic argillites with a few continuous massive sandstones ( $\sim 10 \mathrm{~m}$ thick). Prehnite-pumpellyite facies greenstones occur locally (Fig. 1). Water and methane fluid inclusions in syn-mélange quartz veins indicate mélange formation at depths of $12-14 \mathrm{~km}$ and temperatures of $230-260^{\circ} \mathrm{C}$ (Byrne, 1984; Rowe et al., 2002; Vrolijk et al., 1988). As the mélange formation occurred before, during, and up to basal accretion of the unit (Byrne, 1984), this is taken as an estimate of minimum burial conditions.

\section{SHEAR ZONES AND ULTRAFINEGRAINED FAULT ROCKS: FIELD RELATIONS}

The mélange of Pasagshak Point includes at least three 5-15-m-thick shear zones that are subparallel to local fabric (Figs. 1 and 2). The shear zones are characterized by argillite

(C) 2005 Geological Society of America. For permission to copy, contact Copyright Permissions, GSA, or editing@geosociety.org. Geology; December 2005; v. 33; no. 12; p. 937-940; doi: 10.1130/G21856.1; 3 figures. 
matrix with pervasive scaly fabric, containing rotated and rounded sandstone boudins, and strong downdip lineations on both matrix phacoids and sandstone boudins (shearzone fabric; Figs. 2A, 2B). Extensional veins exist within clasts and fabric-parallel veining is rare. Sandstone clasts vary from submillimeter to $10 \mathrm{~cm}$ along fabric strike, and up to $20 \mathrm{~cm}$ down fabric dip. These shear zones are in a sense "micromélange", but are easily distinguished from background argillite-matrix mélange by a more pervasive shear fabric, and rounding, smaller scale, and rotation of sandstone clasts (Figs. 2A, 2B). One shear zone is exposed for $1 \mathrm{~km}$ along strike and can be correlated for a total of $3 \mathrm{~km}$ along strike. Its base grades into disrupted argillite with variable sandstone bed fragments and boudins. The upper surface of this most continuous shear zone follows the base of a massive sandstone layer.

Dark gray to black, locally vitreous, ultrafine-grained fault rock crosscuts and intrudes the shear zones. The base of the ultrafine-grained layers is sharp and cuts shear-zone scaly fabric at a low $\left(\sim 20^{\circ}\right)$ angle (Figs. $\left.2 \mathrm{~A}-2 \mathrm{C}\right)$. Outcrops show intrusive sills, dikelets, and flow structures, some of which resemble flame structures. These intrusive structures often deform the shear-zone fabric around them (Figs. 2B, 2C). Asymmetrical and sheath folds of the ultrafine-grained fault rock occur along contacts of, and within, the shear zones (Fig. 2C). The massive ultrafinegrained fault rock frequently shows blocky, layerperpendicular jointing (Figs. 2A, 2C). The structurally highest and most continuous example occurs at the top of the most continuously mapped shear zone, just below a massive sandstone (Fig. 1). The ultrafine-grained fault rock layers sometimes occur singly (Fig. 2A), sometimes as a double horizon encasing variably organized fabric of mixed lithologic material, or are overlain by horizons that are transitional to a shear zone and characterized by flow-banding folds (Fig. 2C).

\section{MICROSCOPIC OBSERVATIONS AND CLASSIFICATION OF ULTRAFINEGRAINED FAULT ROCKS}

Ultrafine-grained fault rocks contain predominantly quartz, feldspar, illite, and chlorite. Quartz and feldspar matrix grains are generally $300 \mu \mathrm{m}$ or smaller in diameter. The fabric is characterized by unsorted grains of quartz and feldspar in a microaphanitic matrix (microaphanitic is used here as a nongenetic term for microscopically irresolvable fault rock). The matrix grades from very fine grained chlorite \% clays to completely microaphanitic matrix (Fig. 3A). Where grains are discernable, the matrix varies from slightly foliated chlorite and/or clay to a random fabric mat of lathes.

\section{Overall Appearance}

The optical appearance of the microaphanitic fault rocks varies. Some samples have fine, patchy birefringence textures due to very fine grained chlorite, clay, and quartz. Others are opaque, even in overly thin sections (sub-30 $\mu \mathrm{m}$ thickness). In some layers, the concentration of clastic material is so great and the matrix so opaque as to obscure the nature of the groundmass.

\section{Vesicles and Amygdules}

(C) 2005 Geological Society of America. For permission to copy, contact Copyright Permissions, GSA, or editing@geosociety.org. Geology; December 2005; v. 33; no. 12; p. 937-940; doi: 10.1130/G21856.1; 3 figures. 
Rare vesicles and amygdules occur in the most fine-grained matrix (Fig. 3B). They are very small, isolated, and subspherical (aspect ratio $\sim 1 / 3$ ). Rarely, radiating cracks extend outward from the vesicle walls. Some are partially to totally infilled with quartz, calcite, pyrite, and/or apatite.

\section{Rounded Grains}

Rounded grains are plentiful within aphanitic horizons (Figs. 3A, 3C, 3D); the boundaries of dominantly aphanitic horizons are often gradational into cataclasite, where grain proportion increases over $1 \mathrm{~mm}$ or less from $\sim 10 \%$ to near $100 \%$ of the rock. In the microaphanitic regions, rounded grain populations are entirely quartz, but where grain population increases, grains become more angular, and feldspar grains become more common.

\section{Oxide and Sulfide Crystals}

The aphanitic rocks are generally free of microlite crystals. The exceptions are skeletal pyrite grains, and tiny spherical grains or nodules of titanium oxide and zinc sulfide, which occur in scattered clusters or rows of subspherical grains within the aphanitic matrix (Fig. 3C). Rutile is extremely rare as a detrital mineral in the wall rock, and sphalerite has never been observed elsewhere in the rocks. Pyrite occurs in the host rock in detrital and authigenic fragments, but the grain size in the host argillite and shear zone is very small, while the skeletal and framboidal grains found in the ultrafine-grained fault rocks are an order of magnitude larger (Fig. 3D).

\section{Interpretation and Identification of Pseudotachylyte}

Many of the features described here are consistent with previously reported observations of melt-derived pseudotachylyte, and hold some clues to the conditions under which melting occurred. The microaphanitic fault rock material is interpreted to be pseudotachylyte glass, which is variably devitrified. The amygdules are identified as mineral-filled vesicles formed during cooling of pseudotachylyte glass immediately after formation (Maddock et al., 1987). Amygdule mineral growth may or may not have been coeval with the development of veins in fine extensional joints, which also characterize the glassiest layers of the fault rock.

The rounded grains observed in the aphanitic groundmass are interpreted to be survivor grains. This interpretation is supported by the mineralogy (quartz is more refractory than micas and clays, which dominate source rock) and the smooth rounding of grains, distinct from the angular shape of detrital grains in the source rock and crushing-derived grains in the cataclasite. The pattern of rounded quartz grains within a microaphanitic layer, grading to increasingly angular grains of less refractory minerals (feldspars, clasts of older pseudotachylyte), is consistent with the pattern observed by Otsuki et al. (2003) in variably melted gouge from the Nojima fault zone. The gradational transition between glass-rich, to glass-matrix, to clast-dominated cataclasites (i.e., Fig. 3A) is similar to that described by Berlenbach and Roering (1992). 
The oxide and sulfide mineral grains are distinct from any in the source rock, either by mineralogy (rutile, sphalerite) or by grain size and morphology (coarse skeletal pyrite). Therefore it is likely that these grains are endemic to the ultrafine-grained fault rocks, and that they originated by crystallization from a melt. Skeletal pyrite grains from pseudotachylytes may be indicative of crystallization from a melt. The isotropic, aphanitic ultrafinegrained rocks, which display vesicles, rounded survivor grains, skeletal pyrite, and metallic microlites, are consistent with the identification of pseudotachylyte.

\section{DISCUSSION}

Globally, the upper limit of seismicity in subduction zones varies in depth, but roughly correlates with the $100-150{ }^{\circ} \mathrm{C}$ isotherm in thermal models (Hyndman et al., 1997; Oleskevich et al., 1999). This locality, as well as the Japanese subduction thrust pseudotachylyte locality (Ikesawa et al., 2003), likely formed in the middle to upper seismogenic zone, while the Corsican locality likely formed in the brittle-ductile transition zone (Austrheim and Andersen, 2004; Hyndman et al., 1997). It has been suggested that pseudotachylyte formation is restricted to dry faults (Bjørnerud and Magloughlin, 2004; Sibson, 1975), because the presence of water could lubricate the fault and/or act as a heat sink and prevent the heat buildup needed to cause frictional melting during earthquakes. In contrast, calculations by Dixon and Dixon (1989) demonstrated that the presence of vesicles in a melt requires entraining of available volatiles during pseudotachylyte cooling, because there is insufficient time to nucleate bubbles by degassing, as previously suggested (Maddock et al., 1987). O'Hara and Sharp (2001) demonstrated that microlite isotopic compositions required melt-groundwater interaction during pseudotachylyte formation.

The thickness of the Kodiak pseudotachylytes $(\sim \leq 10 \mathrm{~cm})$ exceeds predications for the maximum melt thickness that could be produced on a single surface $(\sim 1 \mathrm{~cm})$, as melt production is modeled as inherently self-limiting (McKenzie and Brune, 1972). Work by Di Toro et al. (2005) suggests that a thickness of 2-3 cm could be correlated to coseismic slip of $\sim 10 \mathrm{~m}$, so by that relation, a 10 -cm-thick fault vein would require extraordinarily large slip. It is possible that this conflict could be resolved by considering at least three factors: (1) the thick pseudotachylyte veins that are dense with survivor grains contain less melt than a completely glass vein of the same dimension, (2) melting of phyllosilicate source rocks may require less energy consumption (lower heat capacity) than the models assumed, and (3) even pseudotachylyte fault veins that are semiplanar for tens or hundreds of meters could represent accumulated melt from a larger generation plane that has ponded locally. Despite these qualifications, the very thick pseudotachylytes from the Kodiak Islands may well be the products of great earthquakes, which would be expected in this environment.

Dixon and Dixon (1989) showed that the residence time of thin tabular bodies of silicate melt is short (seconds to hours). Flow banding and intercalation with fluidized gouge and entrainment of volatiles and clasts must have immediately followed melt generation and

(C) 2005 Geological Society of America. For permission to copy, contact Copyright Permissions, GSA, or editing@geosociety.org. Geology; December 2005; v. 33; no. 12; p. 937-940; doi: 10.1130/G21856.1; 3 figures. 
therefore occurred during or immediately after seismic rupture. This association requires that the transiently fluidized cataclasite is an earthquake product, formed in the same environment as, and adjacent to, the frictional melting that formed the pseudotachylyte. This determination does not require that all cataclasites have a seismic origin, but demonstrates the possibility that cataclasite could be a seismic signature in the rock record (Otsuki, 2003).

\section{CONCLUSIONS}

The Pasagshak Point locality hosts the thickest and most voluminous subduction thrust pseudotachylytes described to date. The flow-banded bodies indicate that considerable volumes of frictional melt and ultracataclasitic material were rapidly created during seismic rupture. Pseudotachylyte was likely produced in a wet fault, suggesting that the contention that pseudotachylytes form in dry faults may have some exceptions. The pseudotachylyte crosscuts background scaly fabric of a shear zone at a low angle; therefore, it formed by a seismic event that postdated slower stratal disruption processes, which characterize the preexisting mélange and shear zones. The lack of significant overprinting deformation suggests that the pseudotachylyte formation was followed by transfer to a lower strain-rate environment, probably the upper plate of the subduction thrust. The recognition of this pseudotachylyte occurrence style widens our understanding of the record of paleoseismicity in subduction zones. Such deformationally late, outcrop-scale fluidization structures may indicate paleoseismicity in accretionary prisms, even in the absence of pseudotachylyte.

\section{ACKNOWLEDGMENTS}

We thank Alan Rempel for discussions on the thermodynamics of frictional melting. We appreciate the helpful comments of Gaku Kimura, Yuzuru Yamamoto, and an anonymous reviewer that substantially improved this manuscript. The Institute of Geophysics and Planetary Physics at the University of California-Santa Cruz provided assistance for field logistics. This work was supported by the National Science Foundation grant OCE-0203664.

\section{REFERENCES CITED}

Austrheim, H., and Andersen, T.B., 2004, Pseudotachylytes from Corsica: Fossil earthquakes from a subduction complex: Terra Nova, v. 166, p. 193-197.

Berlenbach, J.W., and Roering, C., 1992, Sheathfold-like structures in pseudotachylytes: Journal of Structural Geology, v. 14, p. 847-856, doi: 10.1016/0191-8141(92)90045$\mathrm{X}$.

Bjørnerud, M.G., and Magloughlin, J.F., 2004, Pressure-related feedback processes in the generation of pseudotachylytes: Journal of Structural Geology, v. 26, p. 2317-2323, doi: 10.1016/j.jsg.2002.08.001. 
Byrne, T., 1984, Early deformation in mélange terranes of the Ghost Rocks Formation, Kodiak Islands, Alaska, in Raymond, L.A., ed., Melanges; their nature, origin and significance: Geological Society of America Special Paper 198, p. 21-51.

Cowan, D.S., 1999, Do faults preserve a record of seismic slip? A field geologist's opinion: Journal of Structural Geology, v. 21, p. 995-1001, doi: 10.1016/S01918141(99)00046-2.

Di Toro, G., Pennacchioni, G., and Teza, G., 2005, Can pseudotachylytes be used to infer earthquake source parameters? An example of limitations in the study of exhumed faults: Tectonophysics, v. 402, p. 3-20.

Dixon, J.E., and Dixon, T.H., 1989, Vesicles, amygdules and similar structures in faultgenerated pseudotachylytes: Comment: Lithos, v. 23, p. 225-229, doi: 10.1016/0024- 4937(89)90007-8.

Fisher, D., and Byrne, T., 1987, Structural evolution of underthrusted sediments, Kodiak Islands, Alaska: Tectonics, v. 6, p. 775-793.

Hansen, E.C., 1971, Strain facies: New York, Springer-Verlag, 207 p.

Hyndman, R.D., Yamano, M., and Oleskevich, D.A., 1997, The seismogenic zone of subduction thrust faults: The Island Arc, v. 6, p. 224-260.

Ikesawa, E., Sakaguchi, A., and Kimura, G., 2003, Pseudotachylyte from an ancient accretionary complex; evidence for melt generation during seismic slip along a master décollement?: Geology, v. 31, p. 637-640, doi: 10.1130/00917613(2003)0312.0.CO;2.

Kitamura, Y., Sato, K., Ikesawa, E., Ikehara- Ohmori, K., Kimura, G., Kondo, H., Ujiie, K., Onishi, C.T., Kawabata, K., Hashimoto, Y.M.H., and Masago, H., 2005, Melange and its seismogenic roof decollment: A plate boundary fault rock in the subduction zone - An example from the Shimanto Belt, Japan: Tectonics, (in press).

Lan-Bin, S., Chuan-Yong, L., Chen, X.-D., Xiao- Ou, Z., and Mei-Xiang, B., 1997, Characteristics of fault rocks and paleo-earthquake source along the Koktokay-Ertai fault zone, Xinjiang, China: Acta Seismologica Sinica, v. 10, p. 365-373.

Maddock, R.H., Grocott, J., and Van Nes, M., 1987, Vesicles, amygdules, and similar structures in fault-generated pseudotachylytes: Lithos, v. 20, p. 419-432, doi: 10.1016/0024- 4937(87)90019-3.

Magloughlin, J.F., 1992, Microstructural and chemical changes associated with cataclasis and frictional melting at shallow crustal levels: The cataclasite-pseudotachylyte connection: Tectonophysics, v. 204, p. 243-260, doi: 10.1016/0040-1951(92)90310-3.

McKenzie, D., and Brune, J.N., 1972, Melting on fault planes during large earthquakes: Royal Astronomical Society Geophysical Journal, v. 29, p. 65-78.

O'Hara, K., and Sharp, Z.D., 2001, Chemical and oxygen isotope composition of natural and artificial pseudotachylyte: Role of water during frictional fusion: Earth and Planetary Science Letters, v. 184, p. 393-406.

Oleskevich, D.A., Hyndman, R.D., and Wang, K., 1999, The updip and downdip limits to great subduction earthquakes: Thermal and structural models of Cascadia, south Alaska, SW Japan, and Chile: Journal of Geophysical Research, v. 104, p. 14,96514,991, doi: 10.1029/1999JB900060.

(C) 2005 Geological Society of America. For permission to copy, contact Copyright Permissions, GSA, or editing@geosociety.org. Geology; December 2005; v. 33; no. 12; p. 937-940; doi: 10.1130/G21856.1; 3 figures. 
Otsuki, K., Monzawa, N., and Nagase, T., 2003, Fluidization and melting of fault gouge during seismic slip: Identification in the Nojima fault zone and implications for focal earthquake mechanisms: Journal of Geophysical Research, v. 108, p. 18 p.

Pacheco, J.F., Sykes, L.R., and Scholz, C.H., 1993, Nature of seismic coupling along simple plate boundaries of the subduction type: Journal of Geophysical Research, v. 98, p. 14,133-14,159.

Plafker, G., Moore, J.C., and Winkler, G.R., 1994, Geology of the southern Alaska margin, in Plafker, G., and Berg, H.C., eds., The geology of Alaska: Boulder, Colorado, Geological Society of America, Geology of North America, v. G-1, p. 389449.

Rowe, C.D., Thompson, E., and Moore, J.C., 2002, Contrasts in faulting and veining across the aseismic to seismic transition, Kodiak accretionary complex, Alaska: Eos (Transactions, American Geophysical Union), Conference Proceedings, v. 83, no. 47, Fall Meet. Suppl., Abstract T21A-1060.

Sibson, R.H., 1975, Generation of pseudotachylyte by ancient seismic faulting: Royal Astronomical Society Geophysical Journal, v. 43, p. 775-794.

Spray, J., 1995, Pseudotachylyte controversy: Fact or friction?: Geology, v. 23, p. 11191122, doi: 10.1130/0091-7613(1995)0232.3.CO;2.

Vrolijk, P., Myers, G., and Moore, J.C., 1988, Warm fluid migration along tectonic mélanges in the Kodiak accretionary complex, Alaska: Journal of Geophysical Research, v. 93, p. 10,313-10,324. 


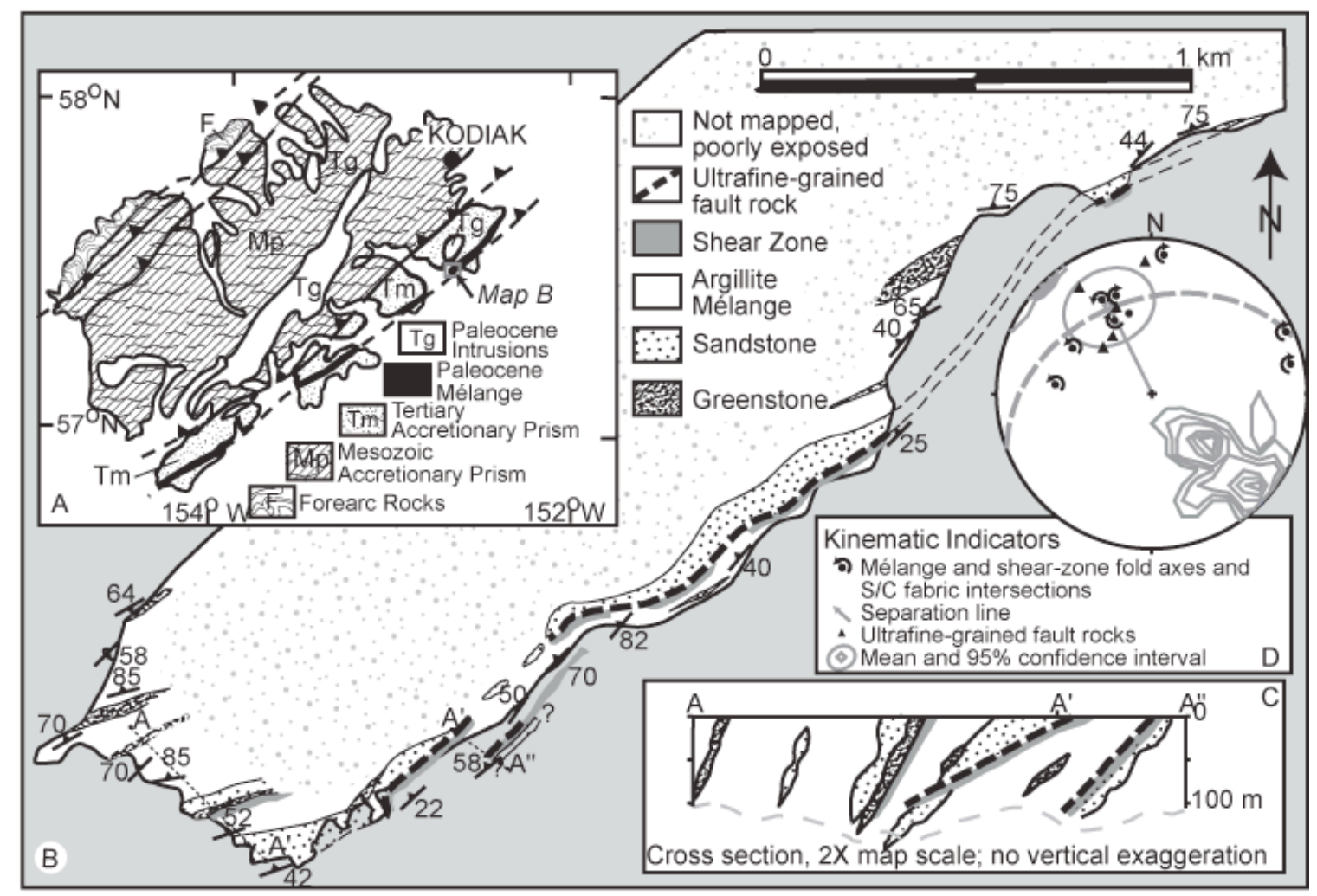

Figure 1. A: Geologic map of Kodiak Islands showing seaward-younging Mesozoic and Cenozoic accretionary prism. B-C: Geologic map and cross-section detail Paleocene argillaceous mélange identified as subduction décollement (Fisher and Byrne, 1987). Disrupted sandstone and greenstone units in argillite matrix are cut by more continuous shear zones and ultrafine-grained fault rock intervals. D: Equal-area lower-hemisphere projection shows contoured poles to $\mathrm{NW}$-dipping mélange foliation $(\mathrm{n}=51$, contoured at $2 \% / 1 \%$ area). Fold axes and S-C intersections from mélange and shear zones indicate NW underthrusting of lower plate; great circle (dashed) with northwesterly trending line separates fields of alternate fold and S-C asymmetry (Hansen, 1971). Mean value of shear indicators from ultrafinegrained fault rock nearly coincides with separation line showing kinematic consistency of mé lange and shear-zone deformation, and slip on ultrafine-grained fault zones. Where visible, steps on slickenlines bounding ultrafinegrained fault rock show underthrusting to NW, similar to mélange and shear-zone deformation. Image was plotted with Stereonet by R. Allmendinger.

(C) 2005 Geological Society of America. For permission to copy, contact Copyright Permissions, GSA, or editing@geosociety.org. Geology; December 2005; v. 33; no. 12; p. 937-940; doi: 10.1130/G21856.1; 3 figures. 


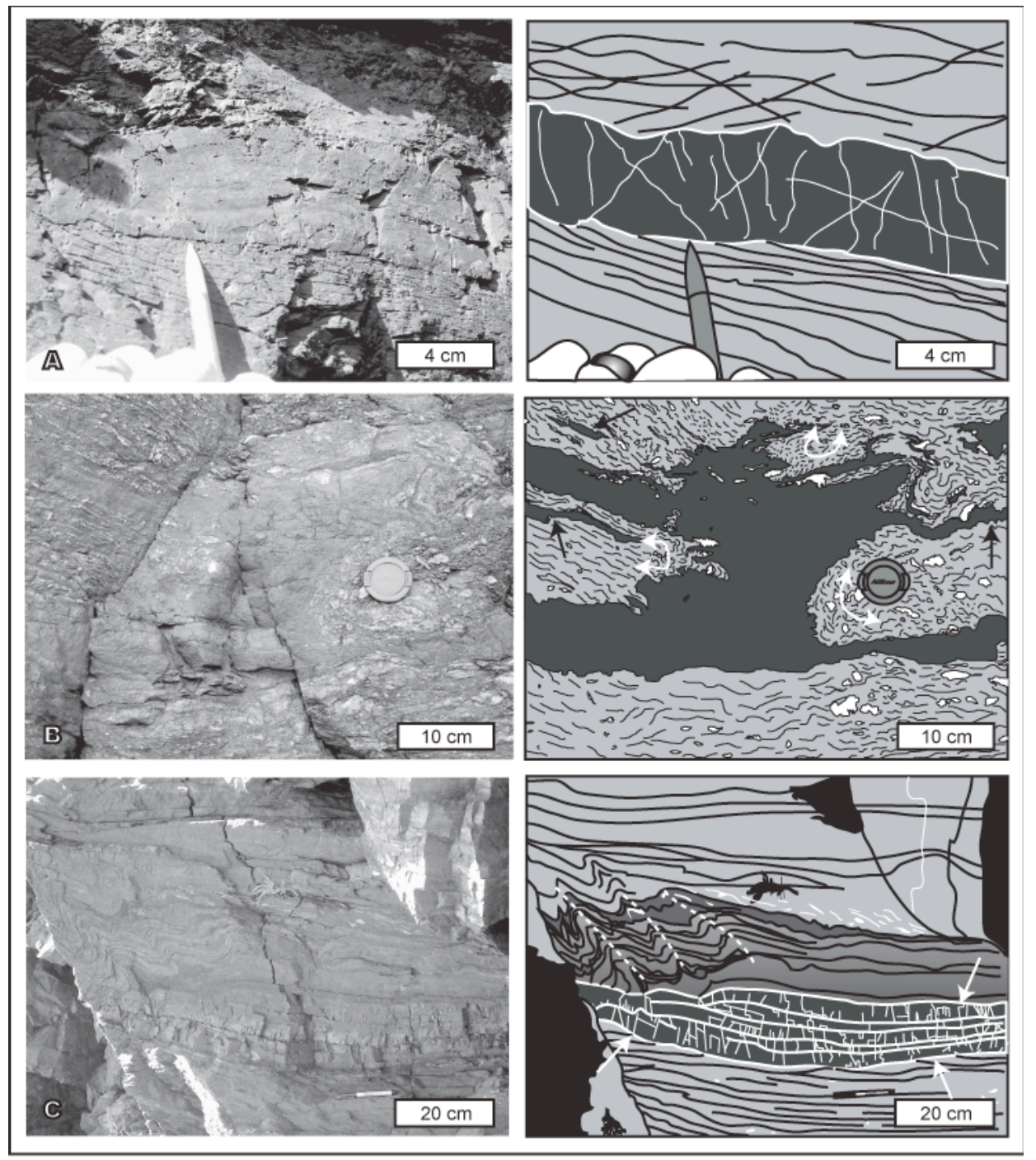

Figure 2. Field photos of ultrafine-grained fault rock within shear zones. A: Field photo and sketch of cherty massive blocky pseudotachylyte. Pseudotachylyte cuts earlier mélange fabric at low angle (indicated by tip of pencil). Boundaries are sharp and semiplanar. B: Field photo and sketch of fluidized intrusion of ultrafine-grained fault rock. Large dike feeds several smaller sills. Shear-zone fabric is deformed (curved white arrows) by upward intrusions, suggesting mobility of shear-zone fabric during intrusion event. Basal layer cuts background shear-zone fabric at low angle and may be rupture surface where ultrafinegrained material was generated. Sills in upper part of intrusion penetrate along shear-zone foliation (black arrows), suggesting that foliation surfaces were weak during intrusion. C: Field photo and sketch of massive blocky pseudotachylyte layers (white arrows) with folded cataclasite layers (dotted white lines indicate axial trace). Asymmetrical folds are seaward vergent, consistent with overall vergence of shear zones and surrounding mélange. Base of blocky pseudotachylyte layer crosscuts shear fabric at low angle. editing@geosociety.org. Geology; December 2005; v. 33; no. 12; p. 937-940; doi: 10.1130/G21856.1; 3 figures. 


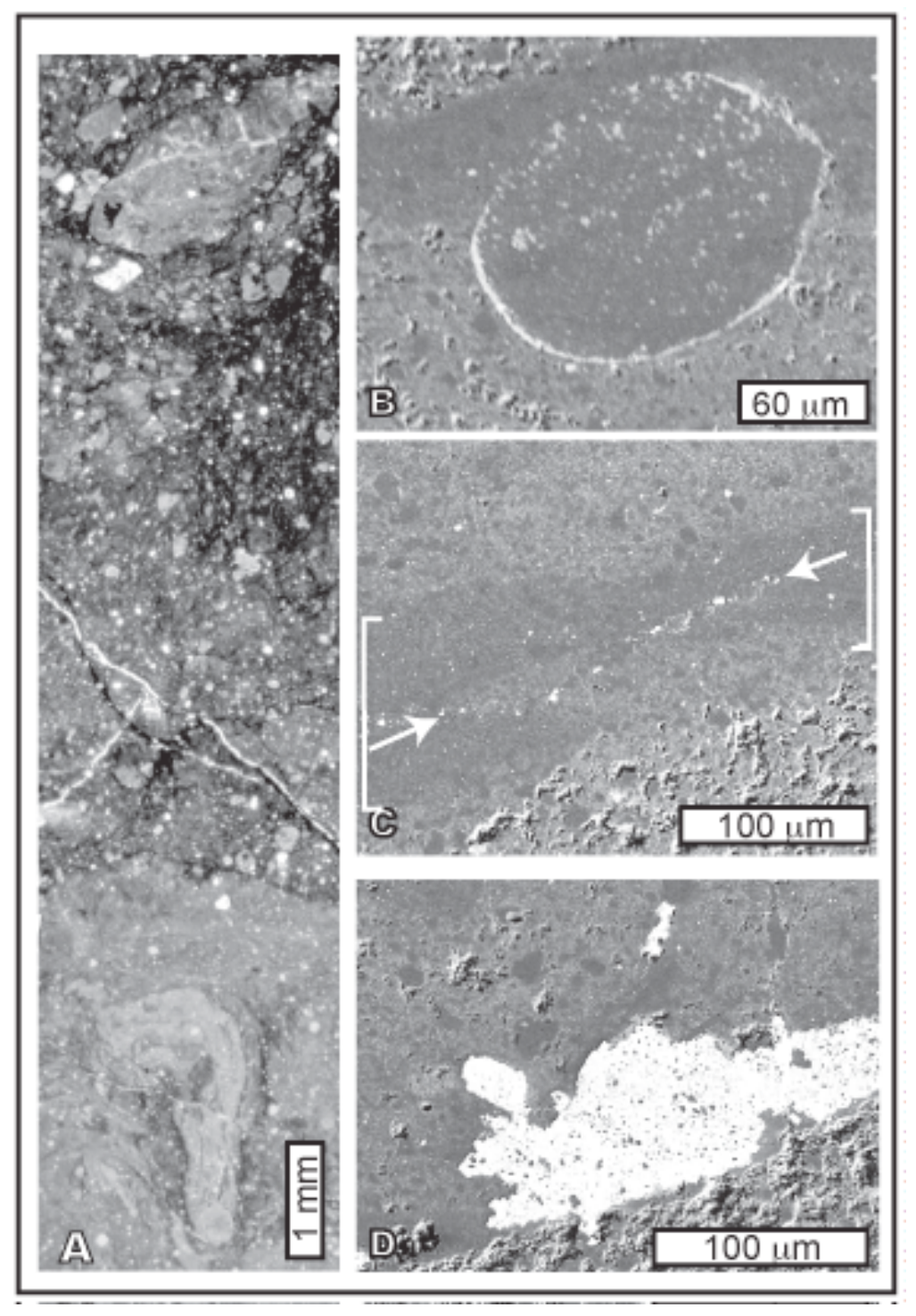

Figure 3. Microphotographs of ultrafinegrained fault rock. A: Photomicrograph of glassfluidized cataclasite contact. Lower light colored material is translucent brown pseudotachylyte glass. Note fiamme-like fluidly folded shard of banded glass. This material grades upward to increasing concentrations of quartz and glass clasts, increasing angularity, and eventually to cataclasites at top of image. Large angular clast of glass is included at top in cataclasite. Plane polarized light. B: Vesicle along boundary between clast-poor pseudotachylyte and cataclasite. Vesicle rim is coated in apatite. Vesicle is empty; bright specks inside vesicle are bits of dust caught in thinsection cement. Backscattered-electron (BSE) image. C: Linear train of TiOx beads (white arrows) in pseudotachylyte glass vein in cataclasite (white brackets) (BSE). D: Skeletal pyrite grain grown along similar boundary to that shown in C. Pyrite has grown around quartz survivor grains in glass matrix (BSE). editing@geosociety.org. Geology; December 2005; v. 33; no. 12; p. 937-940; doi: 10.1130/G21856.1; 3 figures. 